\title{
DESAIN INTERIOR GEDUNG KESENIAN JAKARTA
}

\author{
Sri Rachmayanti \\ Jurusan Desain Interior, Fakultas Komunikasi dan Multimedia, BINUS University \\ Jln. K.H. Syahdan No. 9, Kemanggisan, Palmerah, Jakarta Barat 11480
}

\begin{abstract}
The purpose of this study was to examine the interior design of Gedung Kesenian Jakarta in detail. Another thing is to obtain complete data and analyze the interior design development of GKJ. This study will described in terms of design style and different designs since the early period of this building, the arrival of the Dutch until the present era. Besides aesthetic of interior design, it will review technical factors in the building that related to its interior design, such as acoustic, air conditioning, lighting system, sound system. This research is based on data literartures and interviews with the GKJ. In conclusion, it will discuss the existence of GKJ in relation to local identity, culture and heritage.
\end{abstract}

Keywords: interior design, Gedung Kesenian Jakarta

\begin{abstract}
ABSTRAK
Tujuan dari tulisan ini adalah untuk menguraikan secara detail dari interior desain Gedung Kesenian Jakarta. Hal lainnya adalah untuk memperoleh data yang lengkap dan juga akan menganalisa perkembangan desain Interior dari Gedung Kesenian Jakarta. Akan diuraikan gaya desain dan perubahan yang terjadi dari periode masa awal berdirinya, datangnya Belanda sampai era sekarang. Selain factor estetika dalam ruang, akan diulas juga faktor-faktor teknis dalam bangunan sebuah gedung kesenian yang berkaitan dan erat hubungannya dengan desain interior, seperti akustik, penghawaan, pencahayaan, tata suara. Penelitian ini berdasarkan data literatur dan hasil wawancara dengan pihak GKJ. Dalam simpulan, akan dibahas mengenai keberadaan GKJ dalam kaitannya dengan identitias lokal, warisan budaya dan pelestariannya.
\end{abstract}

Kata kunci: desain interior, Gedung Kesenian Jakarta 


\section{PENDAHULUAN}

Gedung kesenian bisa dipandang sebagai fenomena yang multi status, yaitu sebagai fasilitas berkesenian, sebagai karya budaya yang sewajarnya dipertahankan dan dilestarikan dan juga sebagai komoditi dimana melalui gedung kesenian ada peristiwa ekonomi juga di dalamnya yaitu dimana seniman menjual karya seninya kepada khalayak. Gedung kesenian Jakarta merupakan gedung bersejarah yang kini dilindungi sebagai warisan budaya. Gedung yang sama telah mengalami perkembangan masa, perubahan lingkungan sosial budaya dan iklim sehingga menjadikan gedung ini suatu artefak atau bangunan cagar budaya yang sangat menarik dan penting untuk dikaji.

Definisi benda cagar budaya adalah benda buatan manusia bergerak atau tidak bergerak yang berupa kesatuan atau kelompok atau bagian-bagiannya atau sisa-sisanya yang berumur sekurangkurangnya 50 (lima puluh tahun, atau mewakili masa gaya yang khas dan mewakili masa gaya sekurang-kurangnya 50 (lima puluh) tahun, serta dianggap mempunyai nilai penting bagi sejarah, ilmu pengetahuan dan kebudayaan (Undang-Undang Museum dan Cagar Budaya, 1992). Sedangkan definisi dari Gedung Kesenian, atau sering juga disebut auditorium adalah tempat dimana penonton berkumpul dalam suatu tempat untuk mendegnar atau menyaksikan pertunjukkan, contohnya pertunjukan teater. Kata auditorium berasal dari bahasa latin auditorius tempat untuk mendengar, konsepnya diambil dari auditorium Yunani yang mempunya tempat duduk melingkar.

Gedung Kesenian Jakarta pada awal berdirinya diprakarsai oleh Raffles, dan pembangunannya pada masa gubernur jenderal Daendles di tahun 1814, dilokasi dimana Schowburg Weltevreden ini dibangun, berada dalam landmark kawasan elit pemerintahan Hidia Belanda pada saat itu, dimana di area lapangan banteng dibangun lapangan besar Waterloo Square yang tepat berada dimuka istana atau rumah tinggal Gubernur Jenderal. Bangunan ini bergaya empire. Fungsi awal GKJ adalah sebagai gedung pertunjukan dan tempat pertemuan utnuk kalangan atas. Menurut Heuken (2007), selain Schouwburg Weltevreden, di Batavia juga mempunyai gedung pertemuan umum Sositet De Harmonie dan Sositet Concordia. Kedua bangunan yang disebutkan belakangan telah tidak ada lagi, dilokasi dimana bangunan tersebut berdiri, telah dibangun bangunan lain. Sehingga bangunan GKJ sebagai warisan budaya bangsa patutlah dilestarikan eksistensinya. Dipandang dari segi sosial, penonton GKJ pada masa awal dibangun hanya kalangan penguasa, pejabat dan kaum ningrat Belanda. Salah satu contohnya adalah dalam kunjungannya ke Batavia di 13 Febuari 1837, Pangeran Hendrik dari Belanda mendapat sungguhan sandiwara berjudul 'Graff Lodewijk van Nassau' di Schowburg (nama GKJ pada masa Belanda).

Sebagai gedung bersejarah peninggalan masa lalu yang masih berfungsi sama sampai sekarang yaitu sebagai gedung pertunjukan yang mempertontonkan berbagai perunjukan maupun kesenian baik seni international (musik klasik, tari-tarian dari manca Negara, teater) maupun seni lokal bangsa Indonesia (wayang orang, tarian dan musik daerah). Sehingga timbul beberapa permasalahan yang muncul dan menarik untuk dikaji, seperti apakah gedung kesenian ini telah mengalami perubahan, terutama dalam hal desain interior gedung ataukah telah mengalami penyesesuaian dengan kebutuhan pada masa dan budaya saat ini? Perubahan yang tidak bisa dihindari, agar dapat memenuhi standart untuk menampilkan pertunjukan yang beraneka ragam. Selain itu, apakah ada perubahan di dalam desain interior gedung ini yang sangat diperlukan untuk menjawab kebutuhan jaman yang berhubungan dengan masalah teknis?

\section{METODE}

Metode penelitian yang digunakan adalah berdasarkan studi literature tercetak maupun elektronik dan kunjungan secara langsung ke Gedung Kesenian Jakarta. 


\section{HASIL DAN PEMBAHASAN}

Dalam mengkaji suatu desain interior, ada beberapa hal penting yang perlu diperhatikan antara lain program ruang. Pembagian atau program ruang dari gedung kesenian Jakarta mulai dari depan, seperti: teras, lobi-yang merupakan ruangan transisi antara bagian luar gedung dengan bagian dalam-kemudian ruang auditorium bagian bawah, dan balkon, foyer sisi kanan dan kiri, toilet penonton yang berada di area foyer sisi kanan dan kiri. Panggung, green room, ruang rias, ruang dekorasi, gudang, dan toilet pemain di bagian belakang gedung.

Dimulai dari area teras, terdapat Pintu masuk utama kearah lobby. Desain dari pintu ini kurang mendukung penampilan dari keseluruhan bangunan dimana pada arsitektur maupun interior mencerminkan GKJ yang bergaya Neo-klasik.

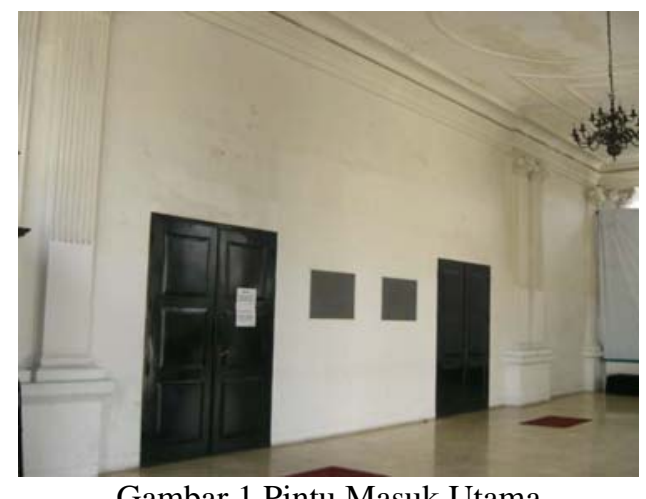

Teras bagian depan dari bangunan megah GKJ ini memiliki 2 (dua) pintu utama yang berukuran 181 x $250 \mathrm{~cm}$, pintu ini dicat berwarna hitam. Dari proporsi ukuran pintu dengan keseluruhan tampak pada bagian depan teras ini terlihat kurang harmonis, karena beberapa elemen bangunan dan interior disekitar lokasi pintu tersebut seperti kolom dengan kepala profil bergaya klasik begitu pula dengan list plafon yang berukuran besar bergaya klasik. Pintu ini terlihat pendek bila dibandingkan dengan proporsi ketinggian ruang depan GKJ. Sebagai pintu masuk utama, penulis merekomendasikan adanya perubahan desain dan proporsi dari ruangan teras utama tersebut.

Selanjutnya adalah lobby area, ceiling plan pada lobby area Gedung Kesenian Jakarta terasa kurang sesuai , karena ketinggian ceiling pada lobby hanya setinggi 2,4 meter, sehingga memberi kesan menekan dan sempit. Padahal dalam bangunan klasik, ukuran tinggi floor to ceiling, berkisar pada jarak 3 sampai 4 meter. Penurunan ceiling ini menurut data dari hasil wawancara, dikarenakan adanya penambahan ruang proyektor saat fungsi GKJ dirubah menjadi bioskop di tahun 1968 - 1970.

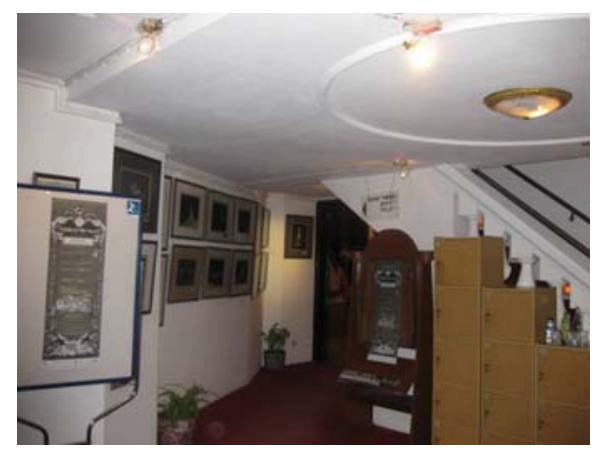

Gambar 2 Ceiling Lobby 
Foyer area atau ruang tunggu penonton atau Pre-function area, adalah ruang yang berfungsi sebagai ruang tunggu penonton (foyer kiri, foyer kanan), terletak disisi samping dari ruang auditorium. Ruangan ini mempunyai ceiling yang cukup tinggi (4,5 meter). Ruangan ini difungsikan sebagai ruang tunggu maupun untuk tea break atau ruang untuk mengudap pada saat istirahat diantara pertunjukan. Pemilihan lantai marmer sudah tepat karena ruangan dipakai untuk menghidangkan makanan dan minuman terkadang air tertumpah ke lantai, sehingga mudah untuk dibersihkan. Penggunaan warna dan permainan pada dinding terasa datar, walaupun sepanjang dinding telah diberi hiasan poster-poster pertunjukan yang telah dimainkan di GKJ.
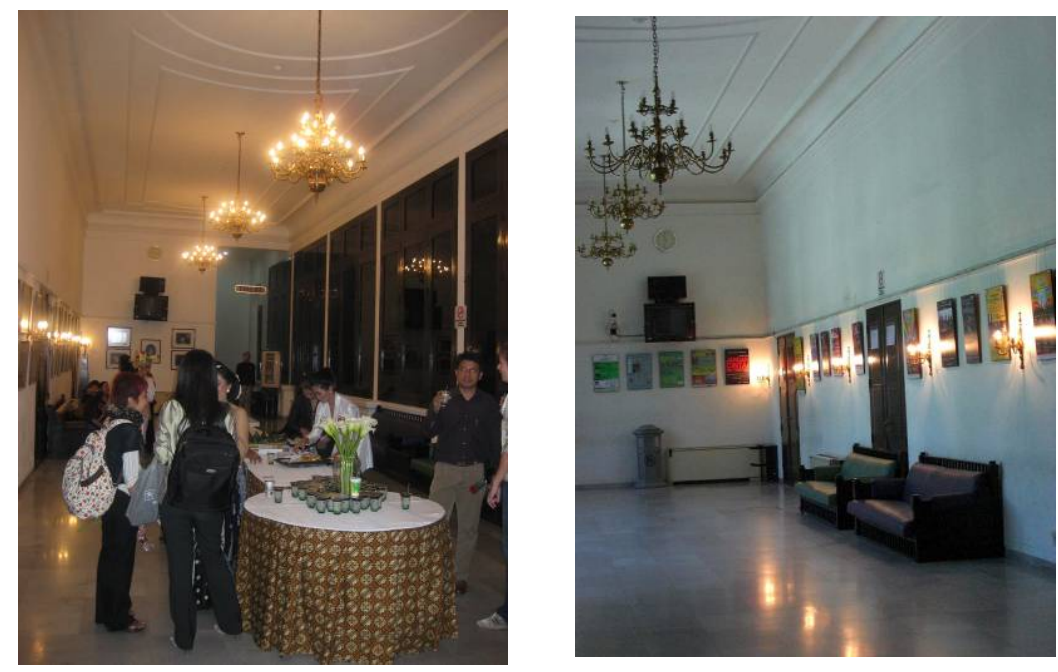

Gambar 3 \& 4 Pre-Function Area

Penyelesaian ceiling dengan menggunakan profil bergaya kolonial dari segi estetis sudah baik, pemasangan lampu chandelier memberikan kesan mewah dan berfungsi sebagai penerangan merata pada seluruh ruang foyer ini, ditambah dengan penerangan dari lampu dinding yang berjajar sepanjang dinding. Penerangan pada siang hari memanfaatkan pencahayaan alami dari jendela-jendela kaca yang berukuran besar yang ada dalam ruang foyer.

Auditorium terbagi menjadi 2 bagian, yaitu area penonton dan area panggung. Auditorium dengan kapasitas 395 kursi di bagian bawah, dan 77 kursi di bagian balkon.

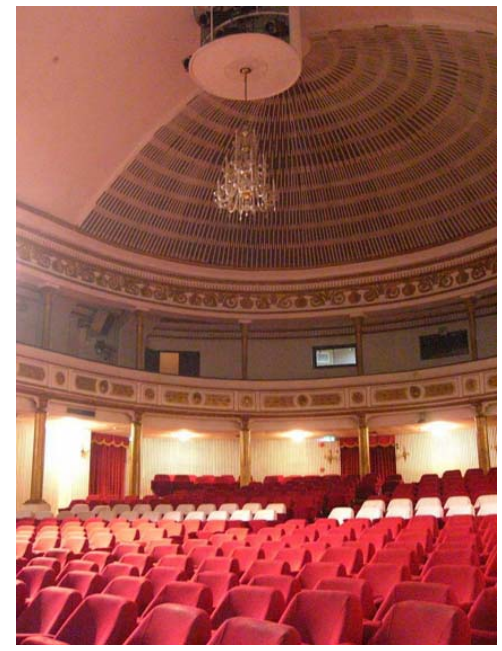

Gambar 5 Auditorium 
Ruang auditorium mempunyai ketinggian 10 meter sampai dengan posisi ceiling tertinggi, membuat ruangan ini berkesan megah dan luas. Lantai area penonton menggunakan carpet berwarna merah. Dinding ruangan ini sebagian besar ditutup panil yang difungsikan sebagai penyerap suara untuk efek akustik yang baik. Dinding tersebut secara dominan dicat warna putih. Plafon berbentuk melengkung setengah lingkaran, telah dilengkapi dengan sistem akustik untuk membantu penyerapan suara pada bagian lengkungan ceiling sisi belakang.

Area panggung, mempunyai ketinggian 80 sentimeter dari lantai penonton. Permukaan lantai peninggalan lama menggunakan kayu, dan kini tetap menggunakan lantai dari bahan kayu solid. Lantai jenis ini baik untuk jenis pertunjukan tari. Permukaan lantai panggung rata, tidak ada area yang dapat diturun-naikkan dengan sistem hidrolik pada lantai seperti tuntutan beberapa panggung untuk pentas opera atau drama modern, dan pertunjukan drama kontemporer. Pihak pengelola GKJ menyediakan level kayu untuk panggung tambahan bila diperlukan dalam pementasan. Level kayu yang tersedia masing-masing berukuran (180 x 90 x 20 sentimeter) sebanyak 25 buah. Ukuran panggung GKJ tinggi 4,5 meter, lebar 10,5 meter, kedalaman 14,8 meter. Ukuran ini bila mengacu pada standard belum termasuk dalam kelompok panggung untuk pementasan skala kecil (12 meter).

Panggung GKJ mempunyai layar utama berwarna merah, selain itu juga dilengkapi dengan beberapa lapis layar di bagian dalam. Pilihan warna layar, yaitu hitam, biru, abu-abu, krem, merah dan kuning. Bar penggantung layar ini juga dapat digunakan untuk menggantung gambar latar belakang bila diperlukan dalam sebuah pertunjukan. Bagian atas panggung juga dilengkapi dengan 5 line penggantung lampu, di setiap line disediakan masing-masing 14 titik lampu (lihat lampiran IV).

Tampak muka layar utama dari panggung GKJ, dari Gambar 6 dapat dilihat bahwa proporsi dari bidang layar utama yang bisa dibuka tutup, dengan bidang layar bagian atas yang tidak terbuka (bidang lengkungan setengah lingkaran di bagian atas) terlihat lebih dominan pada bagian lengkung tersebut. Secara pandangan visual terlihat kurang baik dan megah. Pada bidang tersebut akan lebih baik dari segi penampilan bila ketinggian bidang.

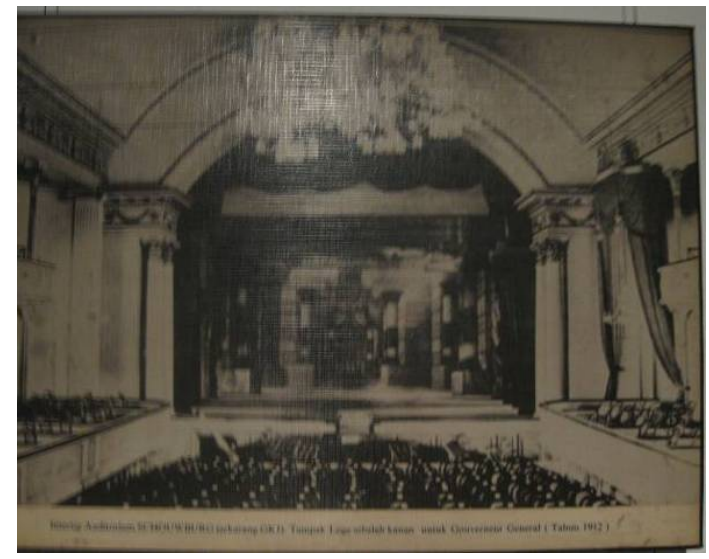

Gambar 6 Tampak Bukaan Layar Panggung

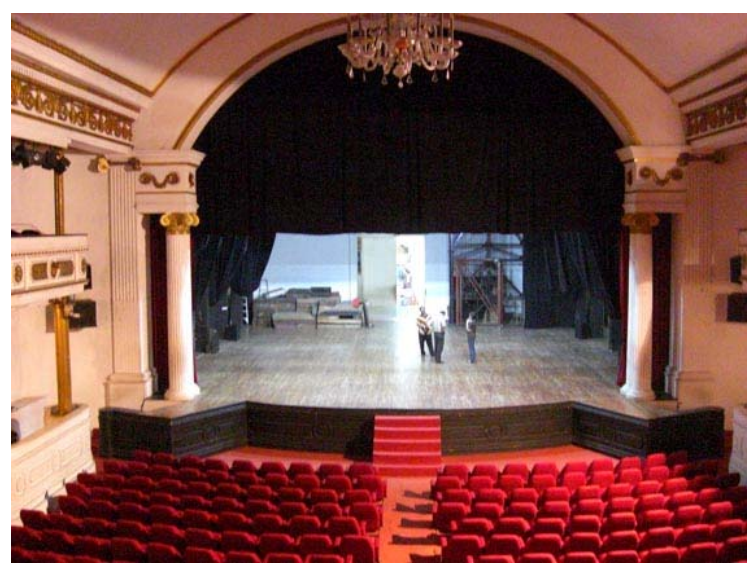

Gambar 7 Tampak Bukaan Layar Panggung Menutupi Separuh Bidang Panggung

Belakang layar dan service area, Gedung Kesenian Jakarta dilengkapi dengan ruanganruangan pendukung panggung yang lokasinya berada di bagian belakang, seperti 2 ruang rias yang telah dilengkapi dengan TV monitor sehingga pemain dapat melihat apa yang dipentaskan dari ruang rias. Ada pula ruang tunggu pemain sebelum pementasan yang juga disebut green room, lokasinya tepat berada di belakang panggung. Ukuran ruang green room ini 6,20 X 10,70 meter. Di bagian belakang dari green room terletak store room, yang difungsikan sebagai ruang untuk mempersiapkan dekorasi panggung. Dari hasil wawancara dengan bapak Mulyanto dari bidang umum GKJ, bangunan 
ini merupakan bangunan baru yang dibuat pada saat konservasi di tahun 1984. Ruang ini dibatasi dengan pintu geser yang cukup besar sehingga dekorasi panggung yang ditempatkan dibelakang dapat mudah dipindahkan ke panggung area. Pada bagian belakang panggung, masih berdekatan dengan green room, juga disediakan toilet wanita dan pria bagi para pemain dan crew yang bertugas, lokasi toilet berada pada sisi kanan dan kiri panggung.

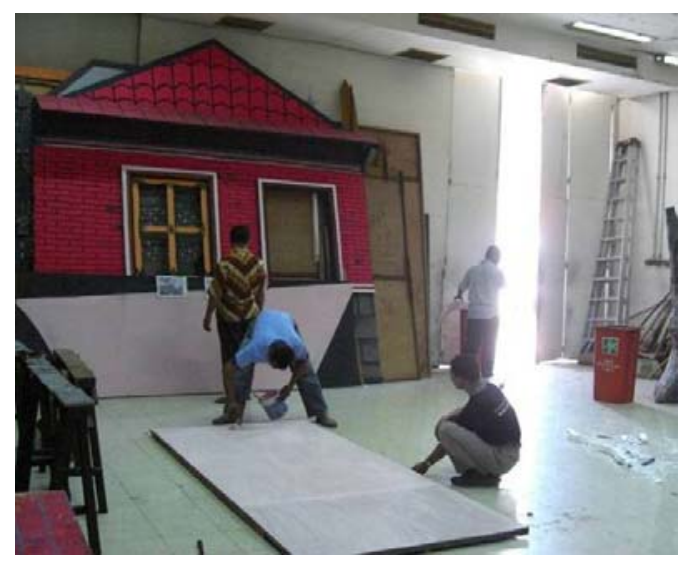

Gambar 8 Ruang Dekorasi

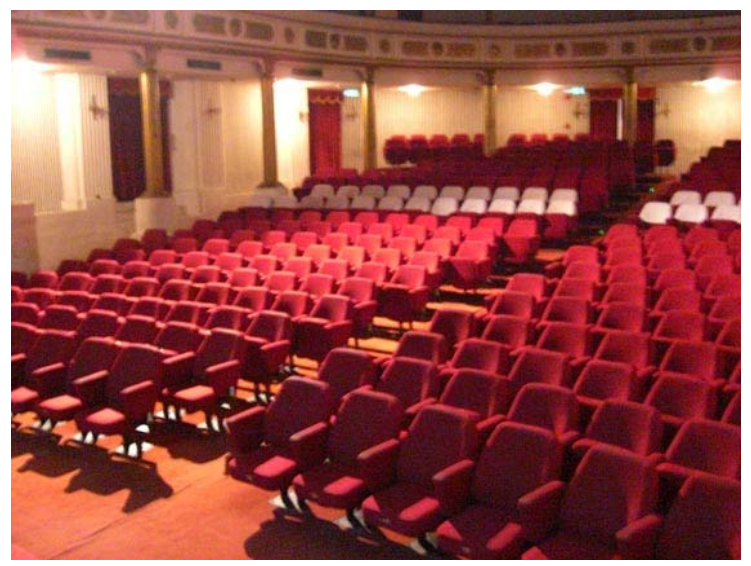

Gambar 9 Penggunaan Dominan Warna Merah dalam Ruang Auditorium

Estetika dan Suasana dakan ruangan auditorium ini didominasi oleh warna merah (yang digunakan pada karpet, curtain dan kursi penonton). Hampir keseluruhan dinding ruang dalam dicat warna putih. Sedangkan ornamen hias pada dinding balkon dan kolom di bagian pinggir ruang auditorium diberi warna emas. Kedua warna tersebut merupakan perlambangan warna-warna kerajaan, royalty, yang melambangkan kemewahan. Warna ruby gelap (merah gelap), melambangkan luxury (kemewahan), dan memberi nuansa interior yang mahal. Warna ini umumnya dipakai dengan dukungan material yang berkualitas baik, seperti pada carpet, pelapis sofa dan kursi (upholstery). Warna tersebut, menurut Starmer (2005), menimbulkan efek mewah, sangat berkualitas dan dari kalangan atas (plush, fine and jet set). Warna seperti tersebut diatas memberi suasana klasikal, ruang yang berberkesan sopan dan elegan, serta berdetail.

Efek dari pemilihan warna dalam ruang, terutama aplikasi aksen pada finishing warna emas di ruang auditorium terlihat memberi suasana mewah dan berkelas. Finishing dengan efek emas atau prada ini dapat menggunakan lembaran prada yang berwarna emas yang lebih berkilau, selain dengan finishing menggunakan cat kuas.

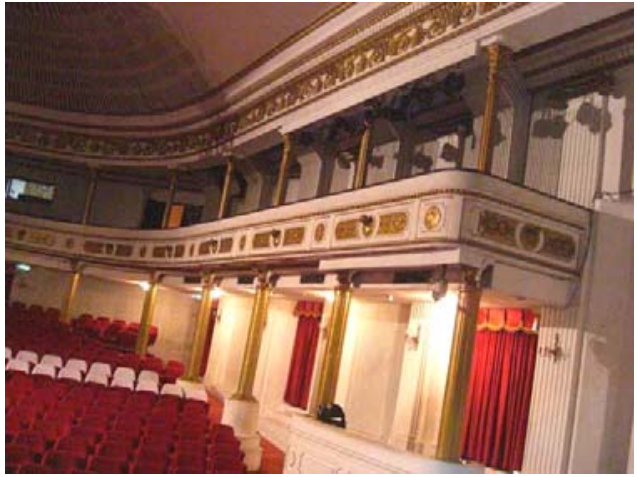

Gambar 10 Interior Ruang dengan Gaya Empire

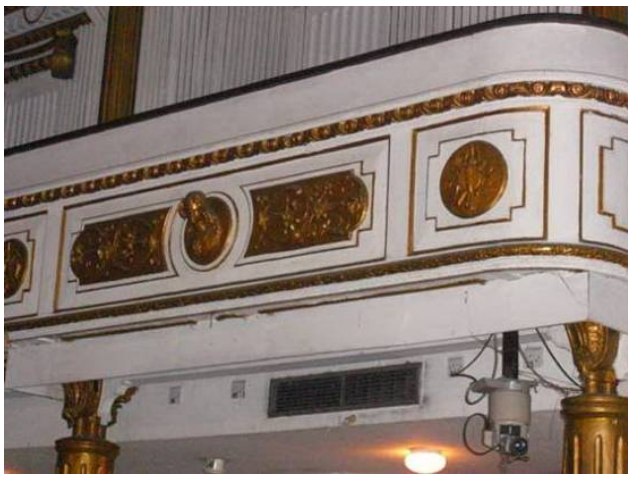

Gambar 11 Penggunaan Ornamen Hias Bergaya Empire dengan Finishing Warna Emas 
Detail ornamen dalam GKJ terlihat cukup konsisten, menggunakan tema yang sama. Dalam teori kajian tentang bentuk estetik dalam karya seni oleh De Witt H. Parker, digunakan asas tema dan asas variasi menurut tema, juga asas tata jenjang. Dimana tema yang diangkat adalah Empire-Rococo detail pengulangan bentuk dan tema detail ornamen dapat dilihat pada dinding sisi balkon dan pada ceiling. Tema dekorasi pada exterior bangunan, tetap dibawa ke dalam dekorasi interior. Dalam gambar dibawah ini terlihat detail relief flora disertai bentuk figur orang, begitupun detail ornamen di sisi balkon, menggunakan detail relief flora dan bentuk figur seorang wanita.

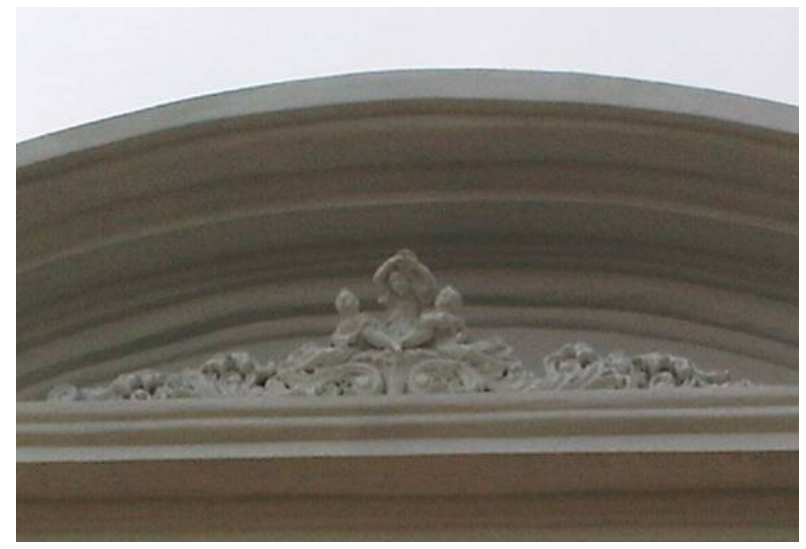

Gambar 12 Detail Relief Flora Disertai Bentuk Figur

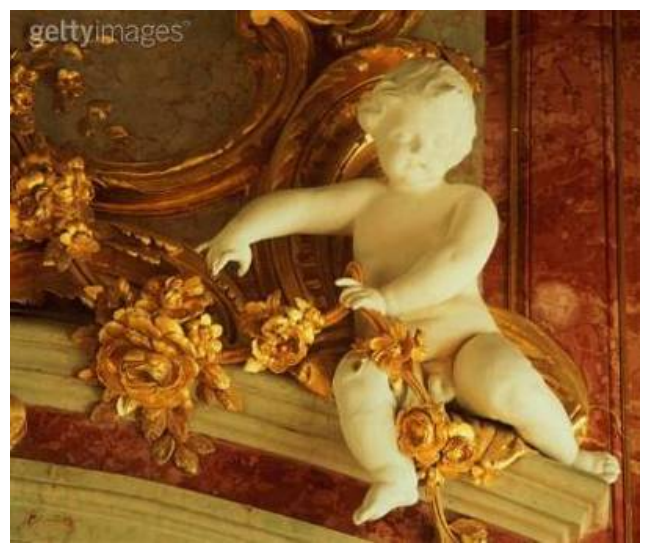

Gambar 13 Detail Dekorasi Gaya Empire - Rococo

Penonton dalam ruang auditorium ini terbagi menjadi dua, penonton di hall lantai dasar dengan kemiringan lantai, dan balkon yang terletak di lantai atas.d Di ruang lantai atas yang dapat dicapai dari tangga (berukuran lebar 80 sentimeter) yang berada disebelah kanan dan kiri lobby, selain balkon, di lantai atas juga terletak ruang kontrol sound system, lighting, dan ruang proyektor atau dokumentasi. Bentuk kepala kolom yang digunakan dalam ruang auditorium menggunakan beberapa model. Setiap desain kepala kolom melambangkan arti tersendiri, penggunaan kolom model Ionic pada exterior bangunan juga mengalami pengulangan pada bagian interior, terlihat pada desain kepala kolom di balkon detail Ionic dikombinasikan dengan finishing warna emas. Untuk kolom penyangga balkon, digunakan kepala kolom model korithia.

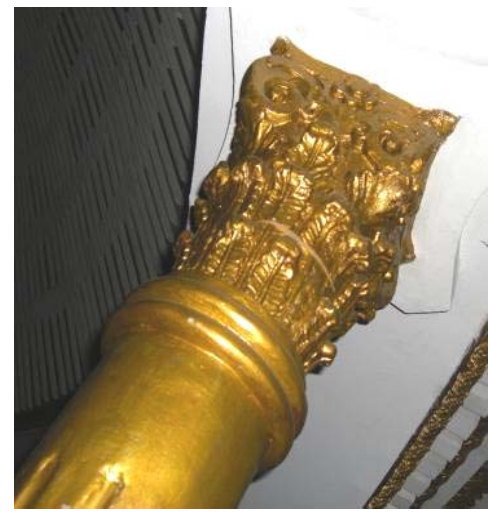

Gambar 14 Detail kepala kolom Korithia

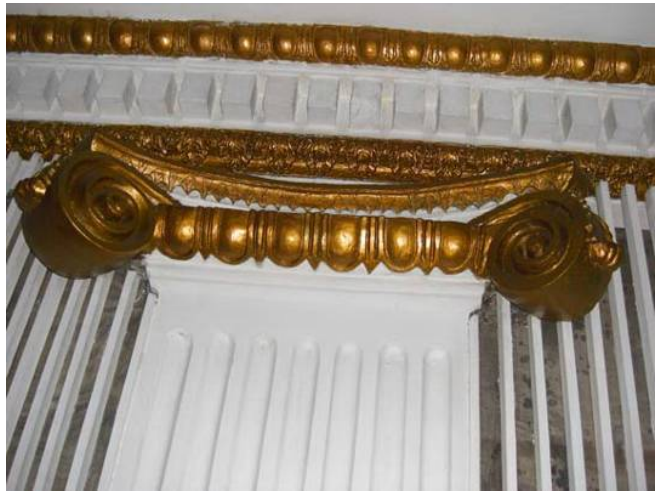

Gambar 15 Detail kolom model Ionic

Untuk kolom utama pada tampak panggung digunakan kolom dengan model mahkota kolom komposit yang merupakan perpaduan dari model korinthia dengan model Ionic. 


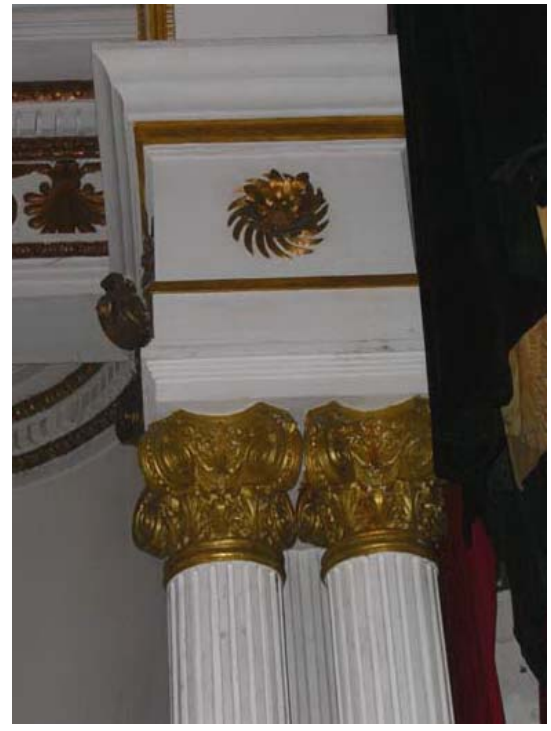

Gambar 16 Detail kepala Kolom Komposit

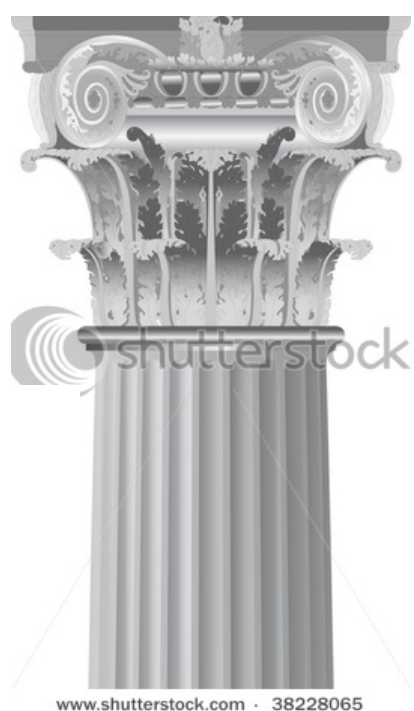

Gambar 17 Detail Kolom Model Komposit

Model komposit tampak lebih megah dan mewah, model ini banyak dipakai untuk bangunan istana, penguasa negara, dan pengembang budaya. Karpet di dalam ruang auditorium menggunakan warna merah mendukung asas kesatuan utuh (the principle of organic unity) dari De Witt, dimana warna merah mermpunyai hubungan timbal balik dari beberapa bagian dalam ruang seperti pada lantai, kursi, curtain, sehingga mendukung keserasian dan kesesuaian tema Empire yang ingin dicapai. Pemakaian lantai karpet juga baik untuk membantu penyerapan suara.

\section{PENUTUP}

Kekurangan dari ruang auditorium tersebut adalah karpet tersebut terkesan sudah lama dan berbau lembab. Bau lembab dari material karpet yang timbul di dalam ruang auditorium bisa disebabkan oleh karena sirkulasi udara yang kurang baik, ataupun karena ada kebocoran di bagian ceiling atau kelembaban di bagian bawah flooring dibalik lapisan karpet. Hal ini mungkin bisa menjadi pertimbangan dari pihak pengelola GKJ untuk melakukan renovasi pada beberapa bagian.

\section{DAFTAR PUSTAKA}

Heuken, S. J. A. (2007). Historical sites of Jakarta. Jakarta: Cipta Loka Caraka.

Republik Indonesia. (1999). Undang-undang Museum dan Cagar Budaya. Jakarta: Lembar Negara No. 27.

Starmer, A. (2005). The color scheme bible: Inpirational palletes for the interior designer. Singapore: Page One. 